\title{
Chemical Constituents from Seeds of Panax ginseng: Structure of New Dammarane-Type Triterpene Ketone, Panaxadione, and HPLC Comparisons of Seeds and Flesh
}

\author{
Sachiko Sugimoto, ${ }^{a}$ Seikou Nakamura, ${ }^{a}$ Hisashi Matsuda, ${ }^{a}$ Niichiro Kitagawa, ${ }^{b}$ and \\ Masayuki YoshIKaWA*,a \\ ${ }^{a}$ Kyoto Pharmaceutical University; Misasagi, Yamashina-ku, Kyoto 607-8412, Japan: and ${ }^{b}$ Koshiro Co., Ltd.; Chuou-ku, \\ Osaka 541-0045, Japan. Received October 6, 2008; accepted December 3, 2008; published online December 5, 2008
}

\begin{abstract}
A new dammarane-type triterpene ketone, panaxadione, was isolated from the seeds of Panax ginseng C. A. MEYer (Araliaceae) together with two dammarane-type and lupane-type triterpenes, an aromatic oligoglycoside, three sterol glycosides, and three dammarane-type triterpene oligoglycosides (ginsenosides $R d, \operatorname{Re}, a_{2} \operatorname{Rg}_{2}$ ). $T$ he structure of a new compound was elucidated on the basis of physicochemical evidence. The relative contents of major ginsenosides in the seeds were compared with those of the flesh parts of young and mature fruits.
\end{abstract}

Key words panaxadione; Panax ginseng; dammarane-type triterpene; ginseng seed; Araliaceae

In the course of our characterization studies on the bioactive saponin constituents from natural medicines ${ }^{1-7)}$ and medicinal flowers, ${ }^{8-12)}$ we have reported the isolation and structure elucidation of malonylginsenosides $\mathrm{Rb}_{1}, \mathrm{Rb}_{2}, \mathrm{Rc}$, and $\mathrm{Rd},{ }^{13,14)}$ notoginsenosides $\mathrm{A}-\mathrm{E}, \mathrm{G}-\mathrm{N}$, and notoginsenic acid, ${ }^{15-17)}$ and quinquenosides $\mathrm{I}-\mathrm{V}^{18}$ ) from the roots of Panax ginseng C. A. Meyer (ginseng), P. notoginseng (BurK) F. H. CHEN (notoginseng), and P. quinquefolium L. (American ginseng). From the flower-buds of $P$. ginseng, $P$. notoginseng, and $P$. quinquefolium, we have also reported the isolation and structure elucidation of floralginsenosides $\mathrm{A}-\mathrm{K}, \mathrm{La}, \mathrm{Lb}-$ $\mathrm{P}^{19-21)}$ notoginsenosides $\mathrm{O}-\mathrm{Q}, \mathrm{S}, \mathrm{T},{ }^{22)}$ and floralquinquenosides $\mathrm{A}-\mathrm{E},{ }^{23)}$ respectively. Furthermore, we characterized immunological adjuvant, ${ }^{17}$ hepatoprotective, ${ }^{22)}$ and gastroprotective $^{21)}$ activities of the principal dammarane-type triterpene saponins from the roots and flowers of those Panax species.

In a continuing study, we examined the chemical constituents from the seeds of $P$. ginseng. The fruits of $P$. ginseng were used as a protective for skin disease, and several dammarane-type triterpene saponins, ginsenosides $R b_{2}$, $\mathrm{Rc}, \mathrm{Rd}, \mathrm{Re}$, and $\mathrm{Rg}_{1}$, have been identified as chemical constituents of the fruits. ${ }^{24)}$

This paper deals with the isolation and structure elucidation of a new dammarane-type triterpene ketone named panaxadione (1) from the seeds of $P$. ginseng as well as the comparison of major ginsenosides using HPLC analysis in the seeds with those in the flesh part of the fruits.

\section{Results and Discussion}

Isolation from Seeds of $\boldsymbol{P}$. ginseng The seeds of $P$. ginseng, which was cultivated in Jilin province of China, were extracted with methanol. The methanolic extract $(11.3 \%$ from the dried seeds) was partitioned into an EtOAc- $\mathrm{H}_{2} \mathrm{O}$ $[1: 1(\mathrm{v} / \mathrm{v})]$ mixture to furnish an EtOAc-soluble fraction $(6.2 \%)$ and aqueous layer. The aqueous layer was further extracted with 1-butanol $(1-\mathrm{BuOH})$ to give $1-\mathrm{BuOH}-(1.7 \%)$ and $\mathrm{H}_{2} \mathrm{O}-(3.4 \%)$ soluble fractions. The EtOAc-soluble fraction was subjected to normal-phase and reversed-phase column chromatographies, and finally HPLC to give a new dammarane-type triterpene, panaxadione $(1,0.00043 \%)$ to- gether with eight known compounds, 20(S)-protopanaxatriol $^{25)}(\mathbf{2}, 0.00052 \%), 3$-keto-20 $(S)$-protopanaxatriol ${ }^{26)}$ (3, $0.0010 \%), 3 \beta$-trans-feruloyloxy-16 $\beta$-hydroxylup-20(29)-ene ${ }^{27)}$ $(4, \quad 0.017 \%)$, daucosterol ${ }^{28)}(5,0.00097 \%), 5 \alpha, 6 \beta$-dihydroxydaucosterol $^{29)}(6,0.0010 \%)$, saringosteryl glucoside ${ }^{30}$ (7, 0.0024\%), and ginsenoside $\operatorname{Rg}_{2}{ }^{31)}(\mathbf{8}, 0.0025 \%)$. The 1$\mathrm{BuOH}-$ soluble fraction was subjected to normal-phase and reversed-phase silica gel column chromatographies and repeated HPLC to give ginsenoside $\operatorname{Rg}_{2}{ }^{31)}(\mathbf{8}, 0.0012 \%)$, ginsenoside $\operatorname{Re}^{32)}(\mathbf{9}, 0.0028 \%)$, ginsenoside $\operatorname{Rd}^{33)}(\mathbf{1 0}, 0.0011 \%)$, and phenethyl alcohol xylopyranosyl $(1 \rightarrow 6)$ glucopyranoside ${ }^{34}$ (11, 0.00072\%).

Structure of Panaxadione Panaxadione (1) was isolated as a white powder with positive optical rotation $\left([\alpha]_{\mathrm{D}}^{23}\right.$ $+177.5^{\circ}$ in $\left.\mathrm{MeOH}\right)$. The IR spectrum of 1 showed absorption bands at 3470 and $1712 \mathrm{~cm}^{-1}$ ascribable to hydroxyl and carboxyl functions. The EI-MS of 1 showed a dehydrated molecular ion peak $\left(\mathrm{M}-\mathrm{H}_{2} \mathrm{O}\right)^{+}$at $m / z 470$ together with a fragment ion peak (i) at $m / z 143$ (base peak), which was known to be characteristic for ocotillone-type triterpenes. ${ }^{35)}$ In the positive-ion FAB-MS of 1, quasimolecular ion peaks were observed at $m / z 511(\mathrm{M}+\mathrm{Na})^{+}$and $m / z 489(\mathrm{M}+\mathrm{H})^{+}$ and high-resolution FAB-MS analysis of the quasimolecular ion $(\mathrm{M}+\mathrm{Na})^{+}$revealed the molecular formula of $\mathbf{1}$ to be $\mathrm{C}_{30} \mathrm{H}_{48} \mathrm{O}_{5}$. The ${ }^{1} \mathrm{H}-\mathrm{NMR}$ (methanol- $d_{3}$ ) and ${ }^{13} \mathrm{C}$-NMR (Table 1) spectra $^{36}$ of $\mathbf{1}$ showed signals assignable to eight tertiary methyls $[\delta 0.80,0.82,1.07,1.09,1.10,1.27,1.28,1.31(3 \mathrm{H}$ each, all s, $\left.\left.\mathrm{H}_{3}-30,19,21,26,27,18,28,29\right)\right]$, two methines bearing an oxygen function $[\delta 3.70$ (t-like, H-24), 3.99 (ddd, $J=4.1,11.0,11.0 \mathrm{~Hz}, \mathrm{H}-6)]$, and four methines $[\delta 1.72,(\mathrm{~m}$, H-5), 1.90 (dd, $J=4.1,13.1 \mathrm{~Hz}, \mathrm{H}-9$ ), 2.52 (ddd, $J=4.8,9.6$, $10.3 \mathrm{~Hz}, \mathrm{H}-17), 3.04$ (d, $J=9.6 \mathrm{~Hz}, \mathrm{H}-13)$ ] together with eight methylenes, four quarternary carbons, two quarternary carbons bearing an oxygen function, and two carbonyl carbons.

The plane structure of $\mathbf{1}$ was constructed on the basis of $\mathrm{H}-\mathrm{H}$ correlation spectroscopy (COSY) and heteronuclear multiple bond connectivity (HMBC) experiments. Thus, the $\mathrm{H}-\mathrm{H}$ COSY experiment on $\mathbf{1}$ indicated the presence of partial structures written in bold lines as shown in Fig. 1. The carbon skeleton and the positions of functional groups were characterized by a HMBC experiment, which showed long- 


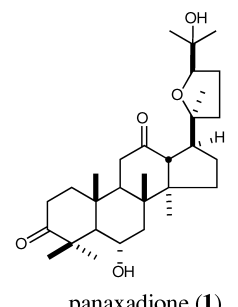

panaxadione (1)

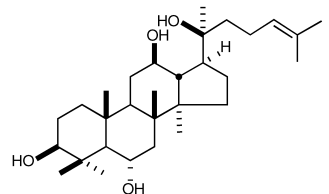

20(S)-protopanaxatriol (2)

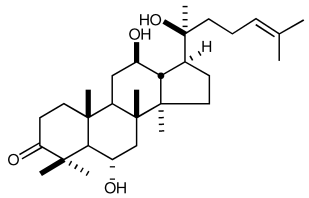

3-keto-20(S)-protopanaxatriol (3)

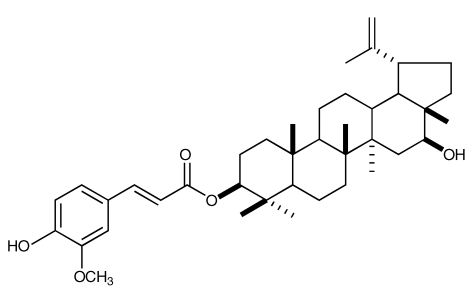

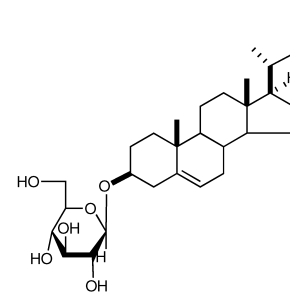

daucosterol (5)

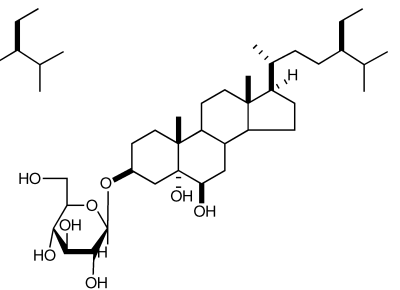

$3 \beta$-trans-Feruloyloxy-16 $\beta$-hydroxylup-20(29)-ene (4)

$5 \alpha, 6 \beta$-dihydroxydaucosterol (6)

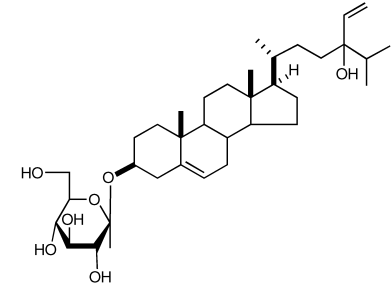

saringosteryl glucoside (7)

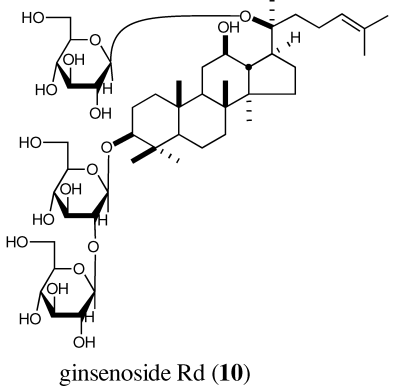

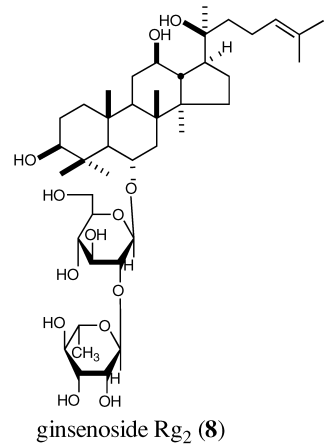

ginsenoside $\operatorname{Rg}_{2}(\mathbf{8})$

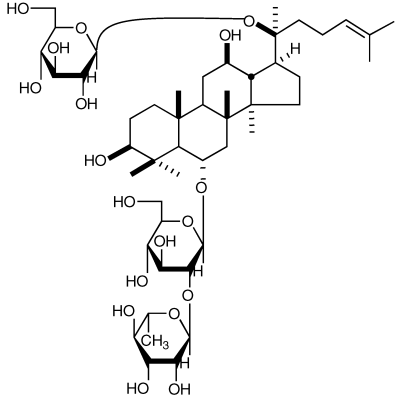

ginsenoside $\operatorname{Re}(\mathbf{9})$

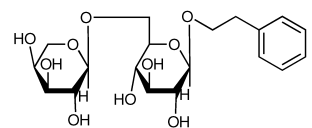

phenethyl alcohol xylopyranosyl $(1 \rightarrow 6)$ glucopyranoside $(\mathbf{1 1})$

Chart 1. Isolated Constituents from the Seeds of Panax ginseng

range correlations between the following protons and carbons: $\mathrm{H}-2$ and $\mathrm{C}-3$; H-5 and C-4, 6, 10; H-7 and C-6, 8, 9; H11 and $\mathrm{C}-9,12 ; \mathrm{H}-13$ and $\mathrm{C}-12,14,17,20 ; \mathrm{H}-19$ and $\mathrm{C}-5,9$, 10; H-18 and C-7, 8; H-21 and C-17, 20, 22; H-26, 27 and C24, 25; H-28, 29 and C-3, 4, 5; H-30 and C-13, 14, 15. The stereostructure of $\mathbf{1}$ was determined by a nuclear Overhauser effect spectroscopy (NOESY) experiment, in which correlations were observed between the following proton pairs: H-6 and $\mathrm{H}-7 \beta, 18,19$; $\mathrm{H}-18$ and $\mathrm{H}-19,13 ; \mathrm{H}-21$ and $\mathrm{H}-17,23 \alpha$, 24; H-24 and H-23 $\alpha$; H-30 and H-17. Furthermore, the proton and carbon signals of the hydrofuran part in the ${ }^{1} \mathrm{H}$ and ${ }^{13} \mathrm{C}-\mathrm{NMR}$ data of $\mathbf{1}$ were superimposable on those of (20S,24R)-ocotillone-type triterpenes. ${ }^{35)}$ On the basis of this evidence, the structure of panaxadione was determined as $6 \alpha$-hydroxy-3,12-dion-(20S),(24R)-epoxy dammarane (1).

Previously, it was reported that ginsenoside Re (10) was obtained from the fruits in a significantly high yield $(6.0 \%$ from the dried fruits) together with ginsenosides $\mathrm{Rb}_{1}, \mathrm{Rc}, \mathrm{Rd}$
(9) and $\operatorname{Rg}_{1}$ at $0.2,0.1,0.1$, and $0.04 \%$ yields, respectively. ${ }^{24)}$ In this time, we merely isolated ginsenosides $\operatorname{Rg}_{2}(\mathbf{8}), \operatorname{Rd}(\mathbf{9})$, and $\operatorname{Re}(10)$ in $0.0032 \%, 0.0011 \%$, and $0.0030 \%$, respectively, from the seeds. In order to clarify the distinction between the fruits and seeds of $P$. ginseng, we examined the principal ginsenoside compositions and relative contents of the young and mature flesh of Japanese $P$. ginseng using HPLC analysis. ${ }^{37)}$ From the immature green and mature red fruits of $P$. ginseng cultivated in Shimane prefecture of Japan, the young and full growth seeds and flesh parts were separated and extracted with $\mathrm{MeOH}$, respectively. The $\mathrm{MeOH}$ extract were subjected to HPLC analysis. ${ }^{37}$ As shown in Table 2, which showed relative contents to those of the roots, both flesh parts contained ginsenosides $\mathrm{Rb}_{1}, \mathrm{Rb}_{2}, \mathrm{Rc}, \mathrm{Re}$, and $\mathrm{Rg}_{1}$ and their total contents were three to four times as amount as those of the roots. The ginsenosides composition and relative contents of the flesh part were similar to those of the flower buds. ${ }^{19-21)}$ Whereas the seeds contained ginseno- 
Table 1. ${ }^{13} \mathrm{C}-\mathrm{NMR}(150 \mathrm{MHz})$ Data of $\mathbf{1}$

\begin{tabular}{|c|c|c|}
\hline Position & A & B \\
\hline 1 & 38.8 & 39.1 \\
\hline 2 & 32.4 & 32.9 \\
\hline 3 & 220.8 & 218.0 \\
\hline 4 & 47.0 & 47.5 \\
\hline 5 & 58.0 & 58.5 \\
\hline 6 & 66.7 & 66.6 \\
\hline 7 & 43.3 & 44.5 \\
\hline 8 & 40.7 & 40.9 \\
\hline 9 & 52.8 & 52.9 \\
\hline 10 & 38.0 & 38.0 \\
\hline 11 & 39.5 & 40.0 \\
\hline 12 & 212.3 & 209.7 \\
\hline 13 & 56.4 & 56.6 \\
\hline 14 & 55.6 & 55.7 \\
\hline 15 & 31.8 & 32.1 \\
\hline 16 & 24.6 & 24.8 \\
\hline 17 & 42.5 & 42.9 \\
\hline 18 & 14.7 & 15.5 \\
\hline 19 & 16.4 & 17.2 \\
\hline 20 & 85.2 & 85.1 \\
\hline 21 & 24.1 & 25.0 \\
\hline 22 & 34.2 & 35.5 \\
\hline 23 & 26.1 & 26.8 \\
\hline 24 & 83.9 & 84.5 \\
\hline 25 & 71.3 & 71.0 \\
\hline 26 & 24.9 & 26.9 \\
\hline 27 & 24.4 & 26.3 \\
\hline 28 & 18.4 & 19.7 \\
\hline 29 & 30.9 & 31.8 \\
\hline 30 & 15.6 & 16.5 \\
\hline
\end{tabular}

Measured in methanol- $d_{3},(\mathrm{~A})$ and pyridine- $d_{5}(\mathrm{~B})$.
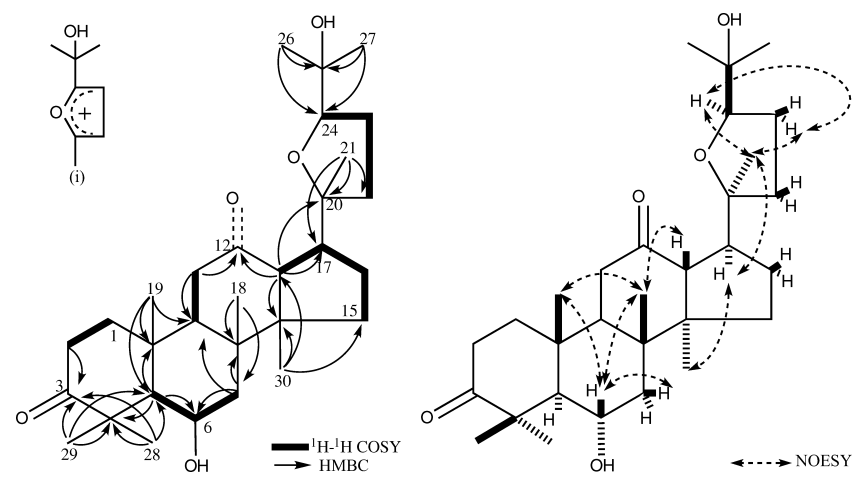

Fig. 1. Significant ${ }^{1} \mathrm{H}-{ }^{1} \mathrm{H}$ COSY, HMBC, and NOESY Correlations and MS Base Peak (i) of Panaxadione (1)

sides $\mathrm{Re}$ and $\mathrm{Rg}_{1}$ and their amounts were very small. This evidence indicated that the ginsenosides of the fruits were principally existent in the flesh part.

\section{Experimental}

The following instruments were used to obtain physical data: specific rotations, Horiba SEPA-300 digital polarimeter $(l=5 \mathrm{~cm})$; IR spectra, Shimadzu FTIR-8100 spectrometer; FAB-MS and high-resolution MS, JEOL JMS-SX 102A mass spectrometer; ${ }^{1} \mathrm{H}-\mathrm{NMR}$ spectra, JEOL EX-270 (270 $\mathrm{MHz}), \mathrm{JNM}-\mathrm{LA} 500(500 \mathrm{MHz})$, and JEOL ECA-600K $(600 \mathrm{MHz})$ spectrometers; ${ }^{13} \mathrm{C}-\mathrm{NMR}$ spectra, JEOL EX-270 (68 MHz) JNM-LA500 (125 $\mathrm{MHz})$, and JEOL ECA-600K $(150 \mathrm{MHz})$ spectrometers with tetramethylsilane as an internal standard; and HPLC detector, Shimadzu RID-6A refractive index and SPD-10Avp UV-VIS detectors. HPLC column, YMC-Pack ODS-A $(250 \times 4.6 \mathrm{~mm}$ i.d. $)$ and $(250 \times 20 \mathrm{~mm}$ i.d. $)$ columns were used for analytical and preparative purposes, respectively.

The following experimental conditions were used for chromatography: or- dinary-phase silica gel column chromatography, Silica gel BW-200 (Fuji Silysia Chemical, Ltd., 150-350 mesh); reverse-phase silica gel column chromatography, Chromatorex ODS DM1020T (Fuji Silysia Chemical Ltd., $100-200$ mesh); TLC, precoated TLC plates with Silica gel $60 \mathrm{~F}_{254}$ (Merck, $0.25 \mathrm{~mm}$ ) (ordinary phase) and Silica gel RP- $18 \mathrm{~F}_{254 \mathrm{~S}}$ (Merck, $0.25 \mathrm{~mm}$ ) (reverse phase); reversed-phase HPTLC, precoated TLC plates with Silica gel RP-18 $\mathrm{WF}_{254 \mathrm{~S}}$ (Merck, $0.25 \mathrm{~mm}$ ); and detection was achieved by spraying with $1 \% \mathrm{Ce}\left(\mathrm{SO}_{4}\right)_{2}-10 \%$ aqueous $\mathrm{H}_{2} \mathrm{SO}_{4}$ followed by heating.

Plant Material The seeds and flower buds of $P$. ginseng were cultivated in Jilin province, China, in November 2005 and identified by one of authors (M. Y.). The young and mature fruits (seeds and flesh) and roots were cultivated in Shimane prefecture of Japan in 2007.

Extraction and Isolation The dried seeds $(1.0 \mathrm{~kg})$ of $P$. ginseng cultivated in Jilin province of China were finely crushed and extracted three times with methanol under reflux for $3 \mathrm{~h}$. Evaporation of the solvent under reduced pressure provided a methanolic extract $(113.3 \mathrm{~g}, 11.3 \%)$. The methanolic extract $(100 \mathrm{~g})$ was partitioned into an EtOAc- $\mathrm{H}_{2} \mathrm{O}[1: 1(\mathrm{v} / \mathrm{v})]$ mixture to furnish an EtOAc-soluble fraction $(55.0 \mathrm{~g}, 6.2 \%)$ and aqueous phase, which was extracted with $1-\mathrm{BuOH}$ to give $1-\mathrm{BuOH}-(15.4 \mathrm{~g}, 1.7 \%)$ and $\mathrm{H}_{2} \mathrm{O}-(29.6 \mathrm{~g}, 3.4 \%)$ soluble fractions.

Normal-phase silica gel column chromatography [BW-200 (Fuji Silysia Co., Ltd., $2.0 \mathrm{~kg})$, hexane: EtOAc $(50: 1 \rightarrow 20: 1 \rightarrow 5: 1 \rightarrow 1: 1) \rightarrow \mathrm{CHCl}_{3}$ : $\mathrm{MeOH}: \mathrm{H}_{2} \mathrm{O}(10: 3: 1 \rightarrow 7: 3: 1$ lower phase $\left.\rightarrow 6: 4: 1(\mathrm{v} / \mathrm{v} / \mathrm{v})) \rightarrow \mathrm{MeOH}\right]$ of the EtOAc-soluble fraction $(50.0 \mathrm{~g})$ gave six fractions [fr. $1(0.3 \mathrm{~g}), 2(36.0$ g), $3(6.4 \mathrm{~g}), 4(0.7 \mathrm{~g}), 5(3.1 \mathrm{~g}), 6(0.06 \mathrm{~g})]$. Fraction $4(0.7 \mathrm{~g})$ was subjected to reversed-phase silica gel column chromatography $\left[21.0 \mathrm{~g}, \mathrm{H}_{2} \mathrm{O}-\mathrm{MeOH}\right.$ $(40: 60 \rightarrow 30: 70 \rightarrow 20: 80 \rightarrow 10: 90, \mathrm{v} / \mathrm{v}) \rightarrow \mathrm{MeOH} \rightarrow$ acetone] followed by $\mathrm{HPLC}\left[\mathrm{H}_{2} \mathrm{O}: \mathrm{MeOH}(5: 95)\right.$ and $\mathrm{H}_{2} \mathrm{O}$ : isopropanol $\left.(20: 80)\right]$ to furnish $3 \beta-$ trans-feruloyloxy-16 $\beta$-hydroxylup-20(29)-ene $(4,134.6 \mathrm{mg})$. Fraction 5 $(3.1 \mathrm{~g})$ was subjected to reversed-phase silica gel column chromatography $\left[100 \mathrm{~g}, \mathrm{H}_{2} \mathrm{O}: \mathrm{MeOH}(40: 60 \rightarrow 30: 70 \rightarrow 20: 80 \rightarrow 10: 90) \rightarrow \mathrm{MeOH} \rightarrow\right.$ acetone $]$ to provide twelve fractions [fr. $5-1(494.3 \mathrm{mg}), 5-2(368.8 \mathrm{mg}), 5-3(231.8$ $\mathrm{mg}), 5-4(364.1 \mathrm{mg}), 5-5(160.3 \mathrm{mg}), 5-6(253.9 \mathrm{mg}), 5-7(70.8 \mathrm{mg}), 5-8$ (65.3 mg), 5-9 (91.5 mg), 5-10 (69.0 mg), 5-11 (247.6 mg), 5-12 (199.9 mg)]. Fraction $5-5(160.3 \mathrm{mg})$ was purified by $\mathrm{HPLC}\left[\mathrm{H}_{2} \mathrm{O}: \mathrm{MeOH}(35: 65)\right]$ to give panaxadione $(1,3.5 \mathrm{mg})$. Fraction $5-6(253.9 \mathrm{mg})$ was purified by HPLC $\left[\mathrm{H}_{2} \mathrm{O}: \mathrm{MeOH}(30: 70)\right]$ to yield ginsenoside $\mathrm{Rg}_{2}(\mathbf{8}, 19.8 \mathrm{mg})$. Fraction $5-7(70.8 \mathrm{mg})$ was separated by HPLC $\left[\mathrm{H}_{2} \mathrm{O}: \mathrm{MeOH}(25: 75)\right]$ to give $20(S)$-protopanaxatriol $(\mathbf{2}, 4.2 \mathrm{mg})$ and 3-keto-20 $(S)$-protopanaxatriol (3, $8.4 \mathrm{mg})$. Fraction 5-9 $(91.5 \mathrm{mg})$ was purified by HPLC $\left[\mathrm{H}_{2} \mathrm{O}: \mathrm{MeOH}(10\right.$ : 90)] to give saringosteryl glucoside $(7,19.5 \mathrm{mg})$. Fraction $5-10(69.0 \mathrm{mg})$ was separated by HPLC $\left[\mathrm{H}_{2} \mathrm{O}: \mathrm{MeOH}(5: 95)\right]$ to furnish hexadecanoic acid $(6.5 \mathrm{mg})$ and $5 \alpha, 6 \beta$-dihydroxydaucosterol $(6,7.8 \mathrm{mg})$. Fraction 5 -11 (247.6 $\mathrm{mg})$ was purified by $\mathrm{HPLC}\left[\mathrm{H}_{2} \mathrm{O}: \mathrm{MeOH}(3: 97)\right]$ to give daucosterol $(\mathbf{5}, 5.2$ $\mathrm{mg}$ ).

The 1-BuOH-soluble phase $(13.0 \mathrm{~g})$ was subjected to normal-phase silica gel column chromatography $\left[400 \mathrm{~g}, \mathrm{CHCl}_{3} \rightarrow \mathrm{CHCl}_{3}: \mathrm{MeOH}: \mathrm{H}_{2} \mathrm{O}(70: 10\right.$ : $1 \rightarrow 50: 10: 1 \rightarrow 35: 10: 1 \rightarrow 20: 3: 1 \rightarrow 7: 3: 1$, lower phase) $\rightarrow \mathrm{MeOH}]$ to give five fractions [fr. $1(2.6 \mathrm{~g}), 2(2.2 \mathrm{~g}), 3(2.0 \mathrm{~g}), 4(4.3 \mathrm{~g}), 5(1.0 \mathrm{~g})]$. Fraction 2 $(2.2 \mathrm{~g})$ was further separated by reversed-phase silica gel column chromatography $\left[60.0 \mathrm{~g}, \mathrm{H}_{2} \mathrm{O}: \mathrm{MeOH}(80: 20 \rightarrow 70: 30 \rightarrow 60: 40 \rightarrow 50: 50 \rightarrow 40: 60 \rightarrow\right.$ $30: 70) \rightarrow \mathrm{MeOH}]$ followed by HPLC $\left[\mathrm{H}_{2} \mathrm{O}: \mathrm{MeOH}(60: 40)\right.$, $\left.(30: 70)\right]$ to give phenethyl alcohol xylopyranosyl $(1 \rightarrow 6)$ glucopyranoside $(11,5.5 \mathrm{mg})$ and ginsenoside $\operatorname{Rg}_{2}(8,8.8 \mathrm{mg})$. Fraction $3(2.0 \mathrm{~g})$ was subjected to reversed-phase silica gel column chromatography $\left[60.0 \mathrm{~g}, \mathrm{H}_{2} \mathrm{O}: \mathrm{MeOH}(40\right.$ : $60 \rightarrow 30: 70 \rightarrow 20: 80 \rightarrow 10: 90) \rightarrow \mathrm{MeOH}]$ followed by HPLC $\left[\mathrm{H}_{2} \mathrm{O}: \mathrm{MeOH}\right.$ (50:50), (20:80)] to give ginsenoside $\operatorname{Re}(\mathbf{9}, 21.3 \mathrm{mg})$ and $\operatorname{Rd}(\mathbf{1 0}, 8.5 \mathrm{mg})$. The known compounds were identified by comparison of their physical data $\left([\alpha]_{\mathrm{D}}\right.$, IR, MS, and ${ }^{1} \mathrm{H}-$ and $\left.{ }^{13} \mathrm{C}-\mathrm{NMR}\right)$ with reported values.

Panaxadione (1): A white powder; $[\alpha]_{\mathrm{D}}^{23}+177.5^{\circ}(c=0.23, \mathrm{MeOH})$; High-resolution positive-ion FAB-MS: Calcd for $\mathrm{C}_{30} \mathrm{H}_{48} \mathrm{O}_{5} \mathrm{Na}(\mathrm{M}+\mathrm{Na})^{+}$: 511.3399. Found : 511.3391; IR (NaCl): $v_{\max } 3470,2991,1712,1468 \mathrm{~cm}^{-1}$; ${ }^{1} \mathrm{H}-\mathrm{NMR}$ (methanol- $\left.d_{3}, 600 \mathrm{MHz}\right) \delta_{\mathrm{H}}: 0.80,0.82,1.07,1.09,1.10,1.27$, $1.28,1.31$ (3H each, all s, $\left.\mathrm{H}_{3}-30,19,21,26,27,18,28,29\right), 1.56(1 \mathrm{H}, \mathrm{m}, \mathrm{H}-$ $7 \alpha), 1.65(1 \mathrm{H}, \mathrm{m}, \mathrm{H}-7 \beta), 1.72(1 \mathrm{H}, \mathrm{m}, \mathrm{H}-5), 1.76(1 \mathrm{H}, \mathrm{m}, \mathrm{H}-23 \beta), 1.89(1 \mathrm{H}$, $\mathrm{m}, \mathrm{H}-23 \alpha), 1.90(1 \mathrm{H}, \mathrm{dd}, J=4.1,13.1 \mathrm{~Hz}, \mathrm{H}-9), 2.52(1 \mathrm{H}, \mathrm{ddd}, J=4.8,9.6$, $10.3 \mathrm{~Hz}, \mathrm{H}-17), 3.04(1 \mathrm{H}, \mathrm{d}, J=9.6 \mathrm{~Hz}, \mathrm{H}-13), 3.70(1 \mathrm{H}, \mathrm{t}-\mathrm{like}, \mathrm{H}-24), 3.99$ $(1 \mathrm{H}$, ddd, $J=4.1,11.0,11.0 \mathrm{~Hz}, \mathrm{H}-6)$; ${ }^{1} \mathrm{H}-\mathrm{NMR}$ (pyridine- $\left.d_{5}, 600 \mathrm{MHz}\right) \delta_{\mathrm{H}}$ : $0.81,0.85,1.22,1.23,1.36,1.41,1.65,1.68$ ( $3 \mathrm{H}$ each, all s, $\mathrm{H}_{3}-19,30,21$, $18,26,27,29,28), 1.91(1 \mathrm{H}, \mathrm{m}, \mathrm{H}-5), 3.16(1 \mathrm{H}, \mathrm{d}, J=9.6 \mathrm{~Hz}, \mathrm{H}-13), 3.95$ $(1 \mathrm{H}, \mathrm{t}, J=7.6 \mathrm{~Hz}, \mathrm{H}-24) ;{ }^{13} \mathrm{C}-\mathrm{NMR}$ : given in Table 1; EI-MS $(\%): 470$ $\left(\mathrm{M}-\mathrm{H}_{2} \mathrm{O}, 13\right), 143$ (100); Positive-ion FAB-MS $m / z: 511(\mathrm{M}+\mathrm{Na})^{+}, 489$ $(\mathrm{M}+\mathrm{H})^{+}$

Sample Preparation for HPLC The powdered sample $(50 \mathrm{mg})$ in water 

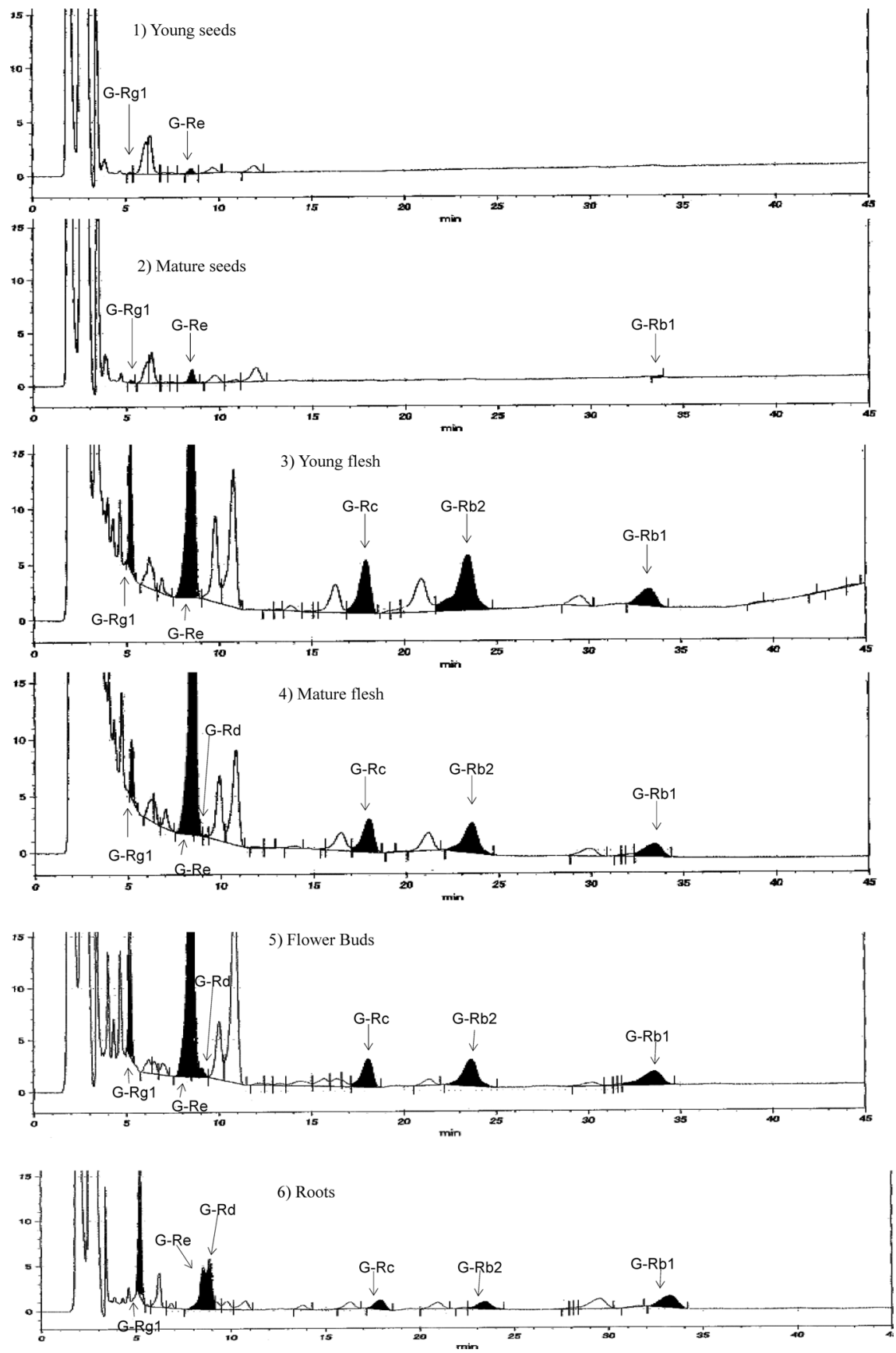

Fig. 2. HPLC Patterns of Ginsenoside Constituents in the Seeds, Flesh, Flower Buds, and Roots

Table 2. The Relative Contents of Ginsenosides in the Young and Mature Seeds and Flesh of Fruits, Flower Buds, and Roots of Japanese P. ginseng

\begin{tabular}{|c|c|c|c|c|c|c|c|}
\hline & $\mathrm{G}-\mathrm{Rb}_{1}$ & $\mathrm{G}-\mathrm{Rb}_{2}$ & G-Rc & $\mathrm{G}-\mathrm{Rd}$ & $\mathrm{G}-\mathrm{Re}$ & $\mathrm{G}-\mathrm{Rg}_{1}$ & Total \\
\hline 1) Young seeds & N.D. & N.D. & N.D. & N.D. & 0.021 & 0.003 & 0.024 \\
\hline 2) Mature seeds & 0.003 & N.D. & N.D. & N.D. & 0.054 & 0.005 & 0.062 \\
\hline 3) Young flesh & 0.221 & 0.755 & 0.461 & N.D. & 2.214 & 0.301 & 3.952 \\
\hline 4) Mature flesh & 0.172 & 0.335 & 0.284 & 0.006 & 2.175 & 0.111 & 3.084 \\
\hline 5) Flower buds & 0.234 & 0.324 & 0.255 & 0.033 & 2.254 & 0.303 & 3.403 \\
\hline 6) Roots & 0.193 & 0.099 & 0.094 & 0.030 & 0.224 & 0.361 & 1.000 \\
\hline
\end{tabular}

Each value in the column means the ratio of the HPLC peak area of the ginsenoside which is calculated on the basis of the HPLC peak area (value: 1.000 ) due to the roots of ginsenosides. 
$(25 \mathrm{ml})$ was ultrasonicated for $30 \mathrm{~min}$. The part $(10 \mathrm{ml})$ of the extract solution $(25 \mathrm{ml})$ was subjected to Sep-pak $\mathrm{C}_{18}$ cartridge column $\left[\mathrm{H}_{2} \mathrm{O} 20 \mathrm{ml}\right.$, $\mathrm{H}_{2} \mathrm{O}-\mathrm{MeOH}(3 \rightarrow 10) 20 \mathrm{ml}, \mathrm{MeOH} 5 \mathrm{ml}$. The $\mathrm{MeOH}$ eluate was subjected to HPLC analysis.

HPLC System and Conditions Shimadzu LC-10A VP HPLC system equipped with CLASS-VP workstation (Shimadzu Co., Ltd., Japan) was used for quantitative analysis. HPLC analysis was performed on a YMCPack NH2 A-612 column $(6.0 \mathrm{~mm}$ i.d. $\times 150 \mathrm{~mm} \mathrm{L.,} 10 \mu \mathrm{l})$ at $40^{\circ} \mathrm{C}$. The mobile phase consisted of acetonitrile-phosphate buffer $(82: 18)$ with a flow rate of $1.4 \mathrm{ml} / \mathrm{min}$. The detective wavelength was set at $203 \mathrm{~nm}$.

Acknowledgments This research was supported by the 21st COE Program, Academic Frontier Project, and a Grant-in-Aid for Scientific Research from the Ministry of Education, Culture, Sports, Science and Technology of Japan.

\section{References and Notes}

1) Yoshikawa M., Nakamura S., Ozaki K., Kumahara A., Morikawa T., Matsuda M., J. Nat. Prod., 70, 210-214 (2007).

2) Morikawa T., Nakamura S., Kato Y., Muraoka O., Matsuda H., Yoshikawa M., Chem. Pharm. Bull., 55, 293-298 (2007).

3) Matsuda H., Nakamura S., Murakami T., Yoshikawa M., Heterocycles, 71, 331-341 (2007)

4) Yoshikawa M., Morikawa T., Kobayashi H., Nakamura A., Matsuhira K., Nakamura S., Matsuda H., Chem. Pharm. Bull., 55, 428-434 (2007).

5) Morikawa T., Matsuda H., Li N., Li X., Yoshikawa M., Helv. Chim. Acta, 90, 2342-2348 (2007).

6) Hu J. N., Zhu X. M., Han L. K., Saito M., Sun Y. S., Yoshikawa M., Kimura Y., Zheng Y. N., Chem. Pharm. Bull., 56, 12-16 (2008).

7) Nakamura S., Hongo M., Sugimoto S., Matsuda H., Yoshikawa M., Phytochemistry, 69, 1565-1572 (2008).

8) Yoshikawa M., Xu F., Morikawa T., Pongpiyadacha Y., Nakamura S., Asao Y., Kumahara A., Matsuda H., Chem. Pharm. Bull., 55, 308316 (2007).

9) Yoshikawa M., Nakamura S., Kato Y., Matsuhira K., Matsuda H., Chem. Pharm. Bull., 55, 598-605 (2007).

10) Yoshikawa M., Morikawa T., Asao Y., Fujiwara E., Nakamura S., Matsuda H., Chem. Pharm. Bull., 55, 606-612 (2007).

11) Yoshikawa M., Wang T., Sugimoto S., Nakamura S., Matsuda H., Harima S., Yakugaku Zasshi, 128, 141-151 (2008).

12) Yoshikawa M., Li X., Nishida E., Nakamura S., Matsuda H., Muraoka O., Morikawa T., Chem. Pharm. Bull., 56, 559-568 (2008).

13) Kitagawa I., Taniyama T., Yoshikawa M., Ikenishi Y., Nakagawa Y., Chem. Pharm. Bull., 37, 2961-2970 (1989).

14) Yoshikawa M., Fukuda Y., Hatakeyama S., Murakami N., Taniyama T., Hayashi T., Kitagawa I., Yakugaku Zasshi, 113, 460 - 467 (1993).

15) Yoshikawa M., Murakami T., Ueno T., Yashiro K., Hirokawa N., Murakami N., Matsuda H., Saijoh R., Tanaka O., Chem. Pharm. Bull., 45, 1039-1045 (1997).

16) Yoshikawa M., Murakami T., Ueno T., Hirokawa N., Yashiro K., Mu- rakami N., Matsuda H., Saijoh R., Tanaka O., Chem. Pharm. Bull., 45, 1056-1062 (1997).

17) Yoshikawa M., Morikawa T., Yashiro K., Murakami T., Matsuda H., Chem. Pharm. Bull., 49, 1452-1456 (2001).

18) Yoshikawa M., Murakami T., Yashiro K., Matsuda H., Saijoh R., Tanaka O., Chem. Pharm. Bull., 46, 647-654 (1998).

19) Yoshikawa M., Sugimoto S., Nakamura S., Matsuda H., Chem. Pharm. Bull., 55, 571-576 (2007).

20) Nakamura S., Sugimoto S., Matsuda H., Yoshikawa M., Heterocycles, 71, 577-588 (2007).

21) Yoshikawa M., Sugimoto S., Nakamura S., Sakumae H., Matsuda H., Chem. Pharm. Bull., 55, 1034-1038 (2007).

22) Yoshikawa M., Morikawa T., Kashima Y., Ninomiya K., Matsuda H., J. Nat. Prod., 66, 922-927 (2003).

23) Nakamura S., Sugimoto S., Matsuda H., Yoshikawa M., Chem. Pharm Bull., 55, 1342-1348 (2007).

24) Yahara S., Kaji K., Tanaka O., Chem. Pharm. Bull., 27, 88-92 (1979).

25) Usami Y., Lin Y. N., Lin A. S., Shibano M., Akiyama T., Itokawa H., Morris-Natschke S. L., Bastow K., Kasai R., Lee K. H., J. Nat. Prod., 71, 478-481 (2008).

26) Anisimov M. M., Shentsova E. B., Shcheglov V. V., Strigina L. I., Uvarova N. I., Levina E. V., Oshitok G. I., Elyakov G. B., Toxicon, 16, 31-36 (1978)

27) Hwang B. Y., Chai H. B., Kardono L. B. S., Riswan S., Farnsworth N. R., Cordell G. A., Pezzuto J. M., Kinghorn A. D., Phytochemistry, 62, 197-201 (2003).

28) Angelika L., Ingrid W., Sabine G., Christa K., Phytochemistry, 66, 2381-2387 (2005)

29) Li S. H., Zhang H. J., Yao P., Niu X. M., Xiang W., Sun H. D., JANPR, 4, 147-154 (2004).

30) Kim S. K., J. Plant Biol., 37, $441-444$ (1994).

31) Ko S. R., Suzuki Y., Kim Y. H., Choi K. J., Biosci. Biotechnol. Biochem., 65, 1223-1226 (2001).

32) Morita T., Kong Y. C., But P. P. H., Ng K. H., Yip T. T., Kasai R., Tanaka O., Chem. Pharm. Bull., 34, 4368-4372 (1986).

33) Ma W. G., Mizutani M., Malterud K. E., Lu S. L., Ducrey B., Tahara S., Phytochemistry, 52, 1133-1139 (1999).

34) Otsuka H., Takeda Y., Yamasaki K., Phytochemistry, 29, 3681-3683 (1990).

35) Takana O., Morita T., Kasai R., Kinouchi J., Sanada S., Ida Y., Shoji J., Chem. Pharm. Bull., 33, 2323-2330 (1985).

36) The ${ }^{1} \mathrm{H}$ - and ${ }^{13} \mathrm{C}-\mathrm{NMR}$ spectra of 1 were assigned with the aid of distortionless enhancement by polarization transfer (DEPT), ${ }^{1} \mathrm{H}-{ }^{1} \mathrm{H}$ correlation spectroscopy $\left({ }^{1} \mathrm{H}-{ }^{1} \mathrm{H}\right.$ COSY $)$, heteronuclear multiple quantum coherence (HMQC), heteronuclear multiple bond connectivity (HMBC), and nuclear Overhauser effect spectroscopy (NOESY) experiments.

37) Yoshikawa M., Fukuda Y., Hatakeyama S., Murakami N., Yamahara J., Taniyama T., Hayashi T., Kitagawa I., Yakugaku Zasshi, 113, 460467 (1993). 